\title{
Self-Efficacy Beliefs Of Prospective Primary Mathematics Teachers About Mathematical Literacy ${ }^{1}$
}

\author{
Güneş Yavuz, Istanbul University, Turkey \\ Berna Cantürk Günhan, Dokuz Eylül University, Turkey \\ Esen Ersoy, Ondokuz Mayis University, Turkey \\ Serkan Narli, Dokuz Eylül University, Turkey
}

\begin{abstract}
The aim of this study was to examine the self-efficacy beliefs about mathematical literacy among teachers of primary school mathematics and the relationship between the self-efficacy beliefs and attitudes towards mathematics. To that end, a descriptive research study was conducted with 550 prospective teachers studying primary school mathematics and teaching at three Turkish universities in three different cities. We obtained data through use of the Mathematical Literacy Self-efficacy Scale and a Scale Measuring Attitude towards Mathematics. The self-efficacy beliefs of prospective teachers about mathematical literacy were compared according to their gender, the grade level(s) they were being trained to teach, and the university they attended. Additionally, the relationship between the self-efficacy beliefs of the prospective teachers about mathematical literacy and their attitudes towards mathematics were examined. We also examined whether attitude is a predictor of self-efficacy beliefs. Based on the research findings, we determined that the self-efficacy beliefs of prospective teachers about mathematical literacy were high and these beliefs did not change according to gender, the grade level(s) they were being trained to teach, or the university they attended. Further, the results of the study revealed a significantly low relationship between the self-efficacy beliefs and attitudes of prospective teachers towards mathematics. The findings of this study indicate that prospective teachers' attitudes towards mathematics are an important predictor of self-efficacy beliefs about mathematical literacy.
\end{abstract}

Keywords: Mathematical Literacy; Self-Efficacy Beliefs about Mathematical Literacy; Attitudes towards Mathematics; Prospective Primary Mathematics Teachers

\section{INTRODUCTION}

C $\mathrm{t}$ is of vital importance that individuals be able to adapt to the rapidly changing world, to access information, and to attain new knowledge. To enhance the quality of mathematics instruction in every stage of the teaching process, mathematical literacy should be identified and developed. Mathematics literacy is significant in terms of the individual's thinking about mathematics, ability to solve problems with a positive attitude towards mathematics, appreciation of the importance of mathematics in everyday life, and ability to use mathematics to acquire basic knowledge and skills (Özgen and Birdal, 2008a). Individuals who are literate in mathematics can use mathematical knowledge in real-life conditions and can use it in making sensible decisions (Hope, 2007). In contrast, individuals whose level of mathematics literacy is low may experience problems performing routine daily tasks with consistency and undergoing the process of life-long learning (Ersoy, 2003). For this reason, particular emphasis should be placed on the improvement of mathematics literacy during student teaching. In this context, OECD - Organisation for Economic Co-Operation and Development (2006) - defined mathematical literacy as the individual's capacity on the issues of identifying and comprehending the importance of

\footnotetext{
${ }^{1}$ This article was presented at the " 21 th National Educational Sciences Congress".
} 
mathematics, reaching the judgments based on strong bases, and being interested in and using mathematics to meet one's own demands as a constructive interested and sensitive citizen.

The level of mathematical literacy in Turkey is compared with that of other countries by means of international examinations in which Turkey and other countries participate. The results are assessed according to certain demographic characteristics, such as gender, socio-economic background, and school policies and practices. Students' levels of mathematical literacy are also examined by the Programme for International Student Assessment (PISA) examinations, which take place once every three years and aim to assess the ability of 15-year-old students to use the knowledge and skills they should have mastered to maneuver competently in today's information society. PISA assessments also include those that aim to measure students' improvement in their levels of mathematical literacy, their knowledge, and their potential to participate more fully and efficiently in society by finding, using, and acknowledging written sources. Additionally, in PISA, literacy is measured according to students' ability to analyze the problems they encounter in various situations, to make reasonable inferences, and to exhibit effective communication skills using the information and skills they acquired in their basic lessons (ERDD, 2005). When the results of various studies are considered, according to the assessments by PISA in 2003, Turkey ranked 33rd among the 41 countries assessed, with an average mathematics score of 423, whereas in 2009, it ranked 43rd among the 65 countries assessed, with a mathematics score of 445. Although its mathematics score increased, Turkey was considered to be in the second tier in the fields of science, mathematics, and reading competency in 2003.

Results from 2009 show that levels in these fields remained the same (Özenç and Arslanhan, 2010). PISA, which particularly focuses on the theme of mathematics literacy, highlights the multitude of students in 2003 who were shown to have the lowest possible level of mathematical literacy and competence (Berberoğlu, 2007). We believe that investigating the reasons for this situation is crucial. Because students need to trust in their own skills to become mathematically literate (Özgen and Bindak, 2008a), teachers' self-efficacy beliefs about their own mathematical literacy must be high so that they can help students improve their mathematical literacy and to enhance the self-confidence of their students. Researchers have reported a positive relationship between teachers' self-efficacy beliefs and their students' success (Usher, 2009) and between teachers' self-efficacy beliefs and their students' level of motivation (Tschannen-Moran and Woolfolk Hoy, 2001; Goddard, Hoy, and Woolfolk-Hoy, 2004). People's self-efficacy beliefs comprise their individual judgments as to how best to organize necessary activities to cope with possible situations and to best carry out these activities (Bandura, 1993). Mathematical literacy, however, defines self-efficacy as individuals' beliefs about and judgment of the situations, their own skills, and the mathematical process they encounter at school, at work, and in daily life (Özgen and Bindak, 2011). The individual whose level of self-efficacy beliefs is high puts in more effort than the individual whose level of such beliefs is low. Attitudes develop after performing the activities in question and individuals sustain these attitudes for a long time (Bandura, 1977). As a result, we believe that it is important for prospective teachers' self-efficacy beliefs to be improved while they are being trained.

Özgen and Bindak (2008b) reported that prospective secondary school mathematics teachers' self-efficacy perceptions are generally positive and that those of male prospective teachers are higher than those of their female counterparts. Similarly, Akkaya, Sezgin Memnun, and Katranci (2012) and Yenilmez and Turğut (2012) reported that the self-efficacy levels of prospective primary and secondary school mathematics teachers' are at favorable levels. Additionally, in a study performed with prospective teachers of science, primary school, and elementary mathematics, a positive, medium-level, significant relationship was discovered between the prospective teachers' self-efficacy beliefs about mathematical literacy and their belief in their overall problem-solving abilities. It was also determined that the mathematical literacy self-efficacy beliefs of these prospective teachers are an important predictor of the beliefs of those individuals in their problem-solving abilities (Sezgin Memnun, Akkaya, and Haciömeroğlu, 2012). In another study performed with prospective teachers of science, primary school, and elementary mathematics, although no significant differences were observed about prospective teachers' gender in determining their self-efficacy beliefs, significant differences were observed about the grade level students were being trained to teach and the field of training in which they specialized (Akkaya and Sezgin Memnun, 2012). However, in a study performed on the self-efficacy beliefs of prospective classroom teachers about mathematical literacy, although no significant difference was observed in these beliefs according to prospective teachers' gender, the field of training in which they specialized, age range, the secondary school from which they graduated, their subject matter expertise, their parents' educational background, and their rate of computer usage while studying 
mathematics, a meaningful difference was found in terms of their study habits (Soytürk, 2011). After an examination of related literature, it was determined that few studies had been carried out about the self-efficacy beliefs of prospective teachers. Based on this finding, the purpose of this study is to determine the self-efficacy beliefs of prospective primary school teachers about mathematical literacy, to compare these findings in terms of various variables, and to determine the relationship between individuals' self-efficacy beliefs about mathematical literacy and their attitudes toward mathematics. In line with the purpose of the study, we attempted to answer the following questions:

1. At what levels are the self-efficacy beliefs of the prospective teachers about mathematical literacy?

2. Are there any differences in the self-efficacy beliefs of the prospective teachers about mathematical literacy according to the universities attended by these individuals?

3. Are there any differences in the mathematical literacy self-efficacy beliefs of the prospective teachers according to the subject area(s) in which they are being trained as teachers?

4. Are there any differences in the self-efficacy beliefs of the prospective teachers about mathematical literacy according to their gender?

5. Is there any relationship between the self-efficacy beliefs of the prospective teachers about mathematical literacy and their attitudes toward mathematics?

6. Are the attitudes of prospective teachers toward mathematics a significant predictor of their self-efficacy beliefs about mathematical literacy?

\section{METHODS}

This study was intended to determine the self-efficacy beliefs of prospective primary mathematics teachers about mathematical literacy and to compare the findings in terms of certain variables. In accordance with this aim, ours is a quantitative research study using a correlational research model.

\section{Population and Sample}

Table 1: Distribution of the Prospective Teachers According to University Attended, Subject-Area Training, \& Gender

\begin{tabular}{|c|c|c|c|c|}
\hline \multirow{2}{*}{ University } & \multirow{2}{*}{ Class } & \multicolumn{2}{|c|}{ Gender } & \multirow{2}{*}{ Total } \\
\hline & & Female & Male & \\
\hline & & n (\%) & n (\%) & $\mathbf{n}$ \\
\hline \multirow{5}{*}{ İstanbul Üniversity } & 1 & $27(0.59)$ & $19(0.41)$ & 46 \\
\hline & 2 & $32(0.62)$ & $20(0.38)$ & 52 \\
\hline & 3 & $28(0.55)$ & $23(0.45)$ & 51 \\
\hline & 4 & $25(0.58)$ & $18(0.42)$ & 43 \\
\hline & Total & $112(0.58)$ & $80(0.42)$ & 192 \\
\hline \multirow{5}{*}{$\begin{array}{l}\text { Dokuz Eylül } \\
\text { Üniversity }\end{array}$} & 1 & $34(0.77)$ & $10(0.23)$ & 44 \\
\hline & 2 & $36(0.84)$ & $7(0.16)$ & 43 \\
\hline & 3 & $31(0.70)$ & $13(0.30)$ & 44 \\
\hline & 4 & $27(0.61)$ & $17(0.39)$ & 44 \\
\hline & Total & $128(0.73)$ & $47(0.27)$ & 175 \\
\hline \multirow{5}{*}{$\begin{array}{l}\text { Ondokuz Mayıs } \\
\text { Üniversity }\end{array}$} & 1 & $33(0.73)$ & $12(0.27)$ & 45 \\
\hline & 2 & $34(0.79)$ & $9(0.21)$ & 43 \\
\hline & 3 & $31(0.69)$ & $14(0.31)$ & 45 \\
\hline & 4 & $33(0.66)$ & $17(0.34)$ & 50 \\
\hline & Total & $131(0.72)$ & $52(0.28)$ & 183 \\
\hline \multirow{5}{*}{ Total } & 1 & $94(0.70)$ & $41(0.30)$ & 135 \\
\hline & 2 & $102(0.74)$ & $36(0.26)$ & 138 \\
\hline & 3 & $90(0.64)$ & $50(0.36)$ & 140 \\
\hline & 4 & $85(0.62)$ & $52(0.38)$ & 137 \\
\hline & Total & $371(0.67)$ & $179(0.33)$ & 550 \\
\hline
\end{tabular}

A total of 550 students majoring in the Department of Mathematics Education, Hasan Ali Yücel Faculty of Education, İstanbul University, İstanbul; Buca Faculty of Education, Dokuz Eylül University, İzmir; and the Faculty 
of Education, Ondokuz Mayis University, Samsun, in Turkey in the 2011-2012 academic year comprised our subject individuals. The control population was comprised of 550 individuals who were enrolled in the stated departments of these universities. In Table 1, we compared the self-efficacy beliefs of the prospective teachers about mathematical literacy according to the universities attended by those individuals, the grade level(s) they were being trained to teach, and their gender.

\section{Data Collection Instrument}

Data were collected using the Mathematical Literacy Self- Efficacy Scale that we created. We also used the Five-Point Likert-Type Mathematics Literacy Self-efficacy Scale, consisting of 25 items, as developed by Özgen and Bindak (2008a). The positive items in the scale are scored from 1 to 5, from "Totally Disagree" to "Totally Agree" and negative items are scored from 1 to 5 . There are four negative and 21 positive items. The highest score possible is 125 and the lowest is 25 . Özgen and Bindak (2008a) reported that the Cronbach alpha internal consistency reliability coefficient of the scale was 0.942 . The Cronbach alpha internal consistency reliability coefficient was reported as 0.909 for the scale, depending on the sampling in this study.

The relationship between the self-efficacy beliefs of prospective teachers about mathematical literacy and their attitudes towards mathematics was also studied. Hence, the 20-item Mathematics Attitude Scale developed by Aşkar (1986) was also used to measure the attitudes of prospective teachers towards mathematics. The scale was composed of 20 Likert-type items, each with five choices; namely, "Totally Suitable", "Suitable", "Undecided", "Unsuitable", and "Totally Unsuitable". There are 10 positive and 10 negative items in the scale. The highest possible score is 100 and the lowest is 20. Aşkar (1986) calculated the Cronbach alpha reliability coefficient of 20 items in the study to be 0.96 . The Cronbach alpha internal consistency reliability coefficient was found to be 0.901 for the scale, depending on the sampling in this study.

\section{Data Analysis}

After data collection was completed, the surveys that were incompletely filled out were excluded from the study and statistical procedures were performed on data from the remaining surveys. Primarily, the span of score intervals for the groups was determined based on interpretations of the responses given by the prospective teachers. The group interval coefficient value was obtained "through division of the difference between the biggest and the lowest value in the set of measurement results by the determined number of groups (Kan, 2009, p. 407)." In this study, the group interval coefficient value was calculated as $(5-1) / 5=0.80$ and the following intervals were taken as reference values in evaluating of the responses obtained through the implementation of the scale: totally agree, 4.21 to 5.00; agree, 3.41 to $<4.21$; undecided, 2.61 to $<3.41$; disagree, 1.81 to $<2.61$; totally disagree, 1.00 to $<$ 1.81. Later, one-way analysis of variance (ANOVA) was performed to disclose the self-efficacy beliefs of prospective teachers about mathematical literacy, as well as the difference among the universities they were attending and grade levels they were preparing to teach. The $t$ test was performed for independent groups to examine the differentiation depending on gender. Additionally, correlation and regression analysis was used to determine the relationship between self-efficacy among prospective teachers about mathematical literacy and the attitudes of those individuals towards mathematics. Büyüköztürk (2010) stated that a Pearson correlation coefficient of between 0.00 and 0.30 shows a low-level relationship, 0.30 to 0.70 shows a medium-level relationship, and 0.70 to 1.00 shows a high-level relationship. The data were analyzed using the SPSS 20 software program.

\section{FINDINGS}

Statistical analyses were undertaken based on the data obtained from the personal information form and the stated self-efficacy beliefs about mathematical literacy from prospective teachers who were enrolled in the Department of Mathematics Education and specialized in primary school education. The first question we sought to answer was At what levels are the self-efficacy beliefs of the prospective teachers about mathematical literacy? In Table 2, we present our findings regarding the mathematical literacy average points of prospective primary school mathematics teachers. 
Table 2: Average Point Scores Concerning Self-Efficacy Beliefs about Mathematical Literacy

\begin{tabular}{|l|c|c|c|c|c|c|}
\hline \multirow{2}{*}{ University } & \multicolumn{5}{|c|}{ Mathematical Literacy Average Points } \\
\cline { 2 - 7 } & $\mathbf{1 . 0 0 - < 1 . 8 1}$ & $\mathbf{1 . 8 1 - < 2 . 6 1}$ & $\mathbf{2 . 6 1 - < 3 . 4 1}$ & $\mathbf{3 . 4 1 - < 4 . 2 1}$ & $\mathbf{4 . 2 1 - 5 . 0 0}$ & Total \\
\cline { 2 - 7 } & \multicolumn{5}{|c|}{$\mathbf{n}(\mathbf{\%})$} & \multicolumn{4}{c|}{$\mathbf{n}$} \\
\hline İstanbul University & $3(1.6)$ & $2(1.0)$ & $35(18.2)$ & $127(66.2)$ & $25(13.0)$ & 192 \\
\hline Dokuz Eylül University & 0 & $3(1.7)$ & $40(22.9)$ & $112(64.0)$ & $20(11.4)$ & 175 \\
\hline Ondokuz May1s University & 0 & $2(1.1)$ & $42(22.9)$ & $122(66.7)$ & $17(9.3)$ & 183 \\
\hline Total & $3(0.5)$ & $7(1.3)$ & $117(21.3)$ & $361(65.6)$ & $62(11.3)$ & $\mathbf{5 5 0}$ \\
\hline
\end{tabular}

As observed in Table 2, only a minority of the average self-efficacy scores of prospective teachers was lower than $2.60(1.8 \%)$ and the average self-efficacy scores of the vast majority of them were higher than 3.41 (76.9), which clearly shows that the vast majority of prospective teachers have self-efficacy average scores regarding mathematical literacy that range between "Agree" and "Totally Agree." This situation shows that the selfefficacy of prospective teachers about mathematics literacy is quite high. Additionally, the distribution at three universities is observed to be highly similar.

The second question we sought to answer was "Are there any differences in the self-efficacy beliefs of the prospective teachers about mathematical literacy according to the universities attended by these individuals? Oneway ANOVA was performed to determine the difference among the average scores of the prospective teachers in mathematical literacy in accordance with the universities these individuals attended. In ANOVA analysis, the equity of groups' variances was first queried by Levene testing. Because $P=0.30(P>0.05)$, according to the Levene test results (i.e., 1.208), the group variances are equal. The findings of ANOVA testing are presented in Tables 3 and 4.

Table 3: Descriptive Analysis Results of the Average Self-Efficacy Beliefs Points in Accordance with the University Attended

\begin{tabular}{|l|c|c|}
\hline \multicolumn{1}{|c|}{ University } & n & Mean (SD) \\
\hline İstanbul University & 192 & $3.70(0.53)$ \\
\hline Dokuz Eylül University & 175 & $3.72(0.49)$ \\
\hline Ondokuz Mayıs University & 183 & $3.68(0.44)$ \\
\hline Total & $\mathbf{5 5 0}$ & $3.70(0.49)$ \\
\hline
\end{tabular}

Abbreviation: SD, standard deviation.

Table 4: ANOVA Analysis Results of the Average Self-Efficacy Beliefs Points in Accordance with University Attended

\begin{tabular}{|l|c|c|c|c|c|}
\hline \multicolumn{1}{|c|}{ Variable } & Sum of Squares & $\boldsymbol{d} \boldsymbol{f}$ & Mean Square & $\boldsymbol{F}$ & \multirow{2}{*}{0.263} \\
\hline Between Groups & 0.126 & 2 & 0.063 & \multirow{2}{*}{0.769} \\
\hline Within Groups & 130.778 & 547 & 0.239 & & \\
\hline Total & $\mathbf{1 3 0 . 9 0 4}$ & 549 & & & \\
\hline
\end{tabular}

As observed in Table 4, there is no difference among the average scores of teacher candidates in selfefficacy about mathematical literacy according to university attended $(F=0.263 ; P>0.05)$.

The third question we sought to answer was Are there any differences in the mathematical literacy selfefficacy beliefs of the prospective teachers according to the subject area(s) in which they are being trained as teachers? One-way ANOVA was performed to determine the difference in the average scores of prospective primary school teachers about mathematical literacy according to the subject area(s) they are being trained to teach. The equity of group variances was first determined via the Levene test in ANOVA analysis. Because $P=0.215(P>$ 0.05 ) according to the results of Levene testing (1.495), the group variances are equal. The results of ANOVA testing are presented in Tables 5 and 6.

Table 5: Descriptive Analysis Results of the Average Self-Efficacy Beliefs Points in Accordance with Class Number

\begin{tabular}{|l|c|c|}
\hline \multicolumn{1}{|c|}{ Class } & n & Mean (SD) \\
\hline 1 & 135 & $3.66(0.50)$ \\
\hline 2 & 138 & $3.67(0.50)$ \\
\hline 3 & 140 & $3.73(0.52)$ \\
\hline 4 & 137 & $3.73(0.42)$ \\
\hline Total & $\mathbf{5 5 0}$ & $3.70(0.49)$ \\
\hline
\end{tabular}

Abbreviation: SD, standard deviation. 
Table 6: One-Way ANOVA Results of the Average Self-Efficacy Beliefs Points in Accordance with Grade Level(S) Prospective Teachers are Being Trained to Teach

\begin{tabular}{|l|c|c|c|c|c|}
\hline \multicolumn{1}{|c|}{ Variable } & Sum of Squares & $\boldsymbol{d f}$ & Mean Square & $\boldsymbol{F}$ & \multirow{3}{*}{0.724} \\
\cline { 1 - 3 } Between Groups & 0.519 & 3 & 0.173 & \multirow{2}{*}{0.538} \\
\hline Within Groups & 130.385 & 546 & 0.239 & & \\
\hline Total & 130.904 & 549 & & & \\
\hline
\end{tabular}

Abbreviation: ANOVA, analysis of variance.

As observed in Table 6, there is no difference among the average scores among prospective teachers in mathematical literacy according to the grade level(s) these individuals are being trained to teach $(F=0.724 ; P>$ $0.05)$.

The fourth question we sought to answer was Are there any differences in the self-efficacy beliefs of the prospective teachers about mathematical literacy according to their gender? The $t$ test results are given in Table 7; this test was undertaken to determine the difference among the average scores of the prospective primary school teachers in mathematical literacy in accordance with their gender.

Table 7: $t$ Test Results of the Average Self-Efficacy Beliefs Points in Accordance with Gender

\begin{tabular}{|l|c|c|c|c|}
\hline \multicolumn{1}{|c|}{ Gender } & n & Mean (SD) & $\boldsymbol{t}$ & \multicolumn{1}{c|}{$\boldsymbol{P}$} \\
\hline Female & 371 & $3.71(0.46)$ & 1.03 & 0.304 \\
\hline Male & 179 & $3.67(0.55)$ & & \\
\hline
\end{tabular}

Abbreviation: SD, standard deviation.

As observed in Table 7, there is no difference in the average self-efficacy beliefs points of prospective teachers about mathematics literacy according to the genders of those individuals $(t=1.03 ; P>0.05)$. The mathematical literacy self-efficacy beliefs of female students $(\bar{X}=3.71)$ and male students $(\bar{X}=3.67)$ are very similar; the groups are of homogenous distribution.

The fifth question we sought to answer was Is there any relationship between the self-efficacy beliefs of the prospective teachers about mathematical literacy and their attitudes towards mathematics? Pearson correlation analysis was performed to uncover the relationship between average self-efficacy beliefs scores regarding mathematical literacy and scores for attitudes towards mathematics (Table 8).

Table 8: Correlation Analysis Results Related to Self-Efficacy Beliefs About Mathematical Literacy and Attitudes towards Mathematics

\begin{tabular}{|c|c|c|c|}
\hline Variable & $\mathbf{n}$ & Pearson Correlation & $P$ \\
\hline $\begin{array}{l}\text { Self-efficacy beliefs about mathematical literacy and } \\
\text { attitudes towards mathematics }\end{array}$ & 550 & 0.112 & $0.009 *$ \\
\hline
\end{tabular}

*Correlation is significant at the 0.01 level $(P<0.01)$.

Our analysis revealed a statistically significant, low-level, positive relationship between self-efficacy beliefs about mathematical literacy and attitudes towards mathematics of prospective teachers.

The final question we sought to answer was Are the attitudes of prospective teachers toward mathematics a significant predictor of their self-efficacy beliefs about mathematical literacy? We performed regression analysis to find out whether a significant predictor of self-efficacy beliefs about mathematical literacy and attitudes towards mathematics existed. The results are included in Table 9.

Table 9: Results of Regression Analysis Prediction of Self-Efficacy Beliefs about Mathematical Literacy According to Prospective Teachers' Attitudes towards Mathematics

\begin{tabular}{|c|c|c|c|c|c|}
\hline Predicting Factor & B & $\begin{array}{c}\text { Standard } \\
\text { Error }\end{array}$ & Beta & $\boldsymbol{t}$ & $\boldsymbol{P}$ \\
\hline Attitude towards mathematics & 0.098 & 0.037 & 0.112 & 2.637 & 0.009 \\
\hline$R=0.112 R^{2}=0.013 \quad F(1,548)=6.956 \quad P>.001$ & & & & \\
\hline
\end{tabular}


Prospective teachers' self-efficacy beliefs about mathematical literacy produce a significant relationship at a low level, together with their attitudes towards mathematics $(F[1.548]=6.956,(P<.01)$. The attitudes towards mathematics, taken together, predicted $1.3 \%$ of the total variation regarding self-efficacy beliefs about mathematical literacy. According to standardized regression coefficient (beta), the relative order of importance of these predicting variables is that self-efficacy beliefs about mathematical literacy are more important than attitudes toward mathematics. When we examine the results of the $t$ test regarding the significance of the regression coefficients, it becomes clear that the factor of attitudes towards mathematics is an important predictor of self-efficacy beliefs about mathematical literacy.

\section{CONCLUSION}

In this study, we aimed to examine the self-efficacy beliefs of prospective primary school teachers about mathematical literacy, depending on several variables, and to examine the relationship between the self-efficacy beliefs of these individuals about mathematical literacy and the attitudes of those individuals towards mathematics. Our first conclusion, based on our study findings, is that there is a high level of mathematical literacy among prospective primary school mathematics teachers. This is a favorable result which corresponds to the results of other studies in the literature (Akkaya, Sezgin Memnun, and Kantranci, 2012; Yenilmez and Turğut, 2012).

Additionally, the other results of this study point out that no difference was determined in self-efficacy beliefs about mathematical literacy according to the gender of prospective teachers, the university they attend, or the grade level(s) they are being trained to teach. This finding can be interpreted as such because variables such as university (Akkaya, Sezgin Memnun, and Katranci, 2012), the grade level(s) the student is being trained to teach (Soytürk, 2011), and gender (Akkaya, Sezgin Memnun, and Katranci, 2012; Soytürk, 2011) correspond to those found in other studies in the literature and because such variables do not affect the self-efficacy level regarding mathematical literacy.

The last result obtained from the study is that there is a positive relationship between the self-efficacy beliefs of prospective teachers about mathematical literacy and their attitudes towards mathematics. This result corresponds to those of a study by Pala (2008) that was carried out with students. From regression analysis, we determined that attitudes towards mathematics are an important predictor for the self-efficacy beliefs of prospective teachers about mathematical literacy.

We recommend further studies be undertaken to examine the self-efficacy beliefs of teachers, or prospective teachers, about mathematical literacy according to other variables. More profound data can be obtained and evaluated through qualitative studies based on observations and interviews. Prospective teachers can receive training regarding how self-efficacy beliefs about mathematical literacy of prospective teachers and their students' level of learning can be improved and how the class atmosphere can be strengthened.

\section{AUTHOR INFORMATION}

Assist. Prof. Dr. Güneş Yavuz is working in the department of primary mathematics education in the faculty of education, İstanbul University, since 2008. She worked in Dokuz Eylul University in the 1992-2008 years. She has a MSc (1993) degree in numeric methods from the Marmara University and a PhD (2006) in mathematics education from the Dokuz Eylül University. Her current research interests include mathematics education, mathematics teacher education, problem solving. E-mail: gyavuz@istanbul.edu.tr (Corresponding author)

Assist. Prof. Dr. Berna Cantürk Günhan is working in the department of primary mathematics education in the faculty of education, Dokuz Eylül University, since 2001. She has a MSc (2001) degree in mathematics and a PhD (2006) in mathematics education from the Dokuz Eylül University. Her primary research interest is mathematics education, mathematics teacher education, problem based learning, geometry learning, drama in mathematics education. E-mail: berna.gunhan@deu.edu.tr

Assist. Prof. Dr. Esen Ersoy is working in the department of primary mathematics education in the faculty of education, Ondokuz Mayıs University since 2003. She has a MSc (2005) degree in statistics from the Ondokuz 
Mayis University and a PhD (2012) in mathematics education from the Dokuz Eylül University. Her current research interests include statistics education, mathematics education, problem based learning. E-mail: esene@omu.edu.tr

Assoc. Prof. Dr. Serkan Narli is working in the department of primary mathematics education in the faculty of education, Dokuz Eylül University, since 1999. He has a MSc (1999) degree in topology and a PhD (2005) in mathematics education from the Dokuz Eylül University. His current research interests include mathematics education, mathematics teacher education, active learning methods, problem based learning, infinity, rough sets and topology. E-mail: serkan.narli@deu.edu.tr

\section{REFERENCES}

1. Akkaya, R. \& Sezgin Memnun, D. (2012). Öğretmen adaylarinin matematiksel okuryazarliğa ilişkin özyeterlik inançlarinin çeşitli değişkenler açisindan incelenmesi (A research on the self-efficacy beliefs about mathematical literacy of preservice teachers in terms of different variables). Dicle Üniversitesi Ziya Gökalp Eğitim Fakültesi Dergisi (Dicle University Journal of the Ziya Gökalp Faculty of Education), 19, 96-111.

2. Akkaya, R., Sezgin Memnun, D. \& Katranci, Y. (2012). Teacher trainees' self-efficacy beliefs about mathematical literacy: Turkey case. In P. Resta (Ed.), Proceedings of Society for Information Technology \& Teacher Education International Conference 2012 (pp. 4330-4337). Chesapeake, VA: AACE.

3. Aşkar, P. (1986). Matematik dersine yönelik tutumu ölçen likert tipi bir ölçeğin geliştirilmesi (Development of a likert type attitude scale for toward mathematics courses). Eğitim ve Bilim (Education and Science), 11(62), 31-36.

4. Bandura, A. (1977). Self-efficacy: Toward a unifying theory of behavioral change. Psychological Review, 84, 191-215.

5. Bandura, A. (1993). Perceived self-efficacy in cognitive development and functioning. Educational Psychologist, 28(2), 117-148.

6. Berberoğlu, G. (2007). Türk bakiş açisindan PISA araştirma sonuçlari (The research results of PISA form Turkish perspective). Konrad Adenauer Stiftung Vakfi (Konrad Adenauer Stiftung Foundation). Retrieved on August 9, 2012. http://www.konrad.org.tr/Egitimturk/07girayberberoglu.pdf

7. Büyüköztürk, Ş. (2010). Sosyal bilimler için veri analizi el kitabi (Handbook for data analysis of the social sciences). Ankara, Turkey: Pegem Publications.

8. $\quad$ ERDD-Education Research and Development Department, (2005). PISA 2003 ulusal nihai raporu (The final report of the national PISA 2003). Ankara: Milli Eğitim Publications.

9. Ersoy, Y. (2003). Matematik okur yazarliği-I: Genel amaçlar ve yeterlikler. (Mathematics Literacy I: General Purposes and Efficiency). Retrieved on August 7, 2012. http://www.matder.org.tr

10. Goddard, R. G., Hoy, W. K. \& Woolfolk Hoy, A. (2004). Collective efficacy: Theoretical development, empirical evidence, and future directions. Educational Researcher, 33(3) 3-13.

11. Hope, M. (2007). Mathematical Literacy. Principal Leadership. 7(5), 28-31.

12. Kan, A. (2009). Ölçme sonuçlari üzerinde istatistiksel işlemler (Statistical processes on the results of measurement). H. Atilgan (Ed.), Eğitimde ölçme ve değerlendirme (Measurement end Evaluation in Education). (pp. 397-456). Ankara: Ani Publications.

13. OECD-Organisation For Economic Co-Operation And Development, (2006). Assessing Scientific, Reading and Mathematical Literacy, A Framework for PISA 2006. Retrieved on August 21, 2012, http://www.pisa.oecd.org

14. Özenç, B. \& Arslanhan, S. (2010). PISA 2009 sonuçlarina ilişkin bir değerlendirme. (An evaluation related to results of PISA 2009). Türkiye Ekonomi Politikalari Araştirma Vakfi (Turkey Economic Politics Research Foundation). Retrieved on September 9, 2012. http://www.tepav.org.tr/upload/files/1292255907PISA_2009_Sonuclarina_Iliskin_Bir_Degerlendirme.pdf

15. Özgen, K. \& Bindak, R. (2008a). Matematik okuryazarliği öz-yeterlilik ölçeğinin geliştirilmesi (The development of mathematics literacy self-efficiacy scale). Kastamonu Eğitim Dergisi (Journal of Kastamonu Education). 16(2), 517-528. 
16. Özgen, K. \& Bindak, R. (2008b). Matematik öğretmen adaylarının matematik okuryazarliği öz-yeterlik algilari (Mathematics literacy self-efficiacy perception of mathematics teacher candidates). VIII. National Science and Mathematics Education Congress, August 27-29, 2008. (p 93). Abant İzzet Baysal University, Bolu, Turkey.

17. Özgen, K. \& Bindak, R. (2011). Lise öğrencilerinin matematik okuryazarliğina yönelik öz-yeterlik inançlarinin belirlenmesi (Determination of self-efficacy belief of mathematics literacy for high school students). Kuram ve Uygulamada Eğitim Bilimleri (Educational Sciences: Theory and Practice), 11(2), 1073-1089.

18. Pala, N., M. (2008). PISA 2003 sonuçlarina göre öğrenci ve sinif özelliklerinin matematik okuryazarliğina ve problem çözmeye etkisi (The effect of student and class characteristics on mathematical literacy and problem solving in accordance with PISA 2003 results). Unpublished Master Thesis, Balikesir University, Balikesir, Turkey.

19. Sezgin Memnun, D., Akkaya, R. \& Haciömeroğlu, G. (2012). The effect of prospective teachers' problem solving beliefs on self-efficacy beliefs about mathematical literacy. Journal of College Teaching \& Learning, 9(4), 289-298.

20. Soytürk, İ. (2011). Sinif öğretmenliği adaylarinin matematik okuryazarliği öz-yeterlikleri ve matematiksel problem çözmeye yönelik inançlarinin araştirilmasi (An investigation of classroom teacher candidates' selfefficacy about mathematical literacy and their beliefs about mathematical problem solving). Unpublished Master Thesis, İstanbul University, Social Sciences Institute, Istanbul, Turkey.

21. Tschannen-Moran, M. \& Woolfolk Hoy, A. (2001). Teacher efficacy: Capturing an elusive construct. Teaching and Teacher Education, 17, 783-805.

22. Usher, E. L. (2009). Sources of middle school students' self efficacy in mathematics: a qualitative investigation. American Educational Research Journal, 46(1), 275-314.

23. Yenilmez, K. \& Turğut, M. (2012). Matematik öğretmeni adaylarinin matematik okuryazarliği özyeterlik düzeyleri (Mathematics literacy self-efficacy levels of mathematics teachers candidates). $3^{\text {rd }}$ International Conference on New Trends in Education and Their Implications. April 26-28, 2012, Antalya, Turkey. 
NOTES 